\title{
Bent Holm
}

\section{Kongen og Narren \\ Symbol, teatralitet, spektakularitet i barokkens teater}

Der tales i undertitlen om barokkens teater, ikke om barokteatret. Ud fra den enkle betragtning, at barokken i sin grund kan forstås som teater. Når der i denne sammenhæng tales om barok, knyttes begrebet intimt til absolutismen, enevoldregimet med dets symbolsk-metafysiske overbygning. Ikke at tidligere tiders regenter ikke også havde spillet på de overjordiske relationer af antikt og kristent tilsnit. Således kan Chr. 4. ses i såvel romersk imperial som Kristi lignelse. ${ }^{1}$ Men med den guddommeligt sanktionerede, centralistiske absolutisme accentueres den symbolske dimension, kongens mytiske status, hans rolle. Modellen leveres af Ludvig 14. i Frankrig, hvis totale projekt involverer et massivt og effektivt fungerende propagandaapparat til indarbejdelse af den enkle kendsgerning, at kongen er en gud. Den egentlige virkelighed placerer sig herefter i den symbolske dimension, kun fiktionen er reel. Denne model for den metafysisk-patriarkalske enevælde sætter sig voldsomt igennem ved Europas hoffer. Og i høj grad også i Danmark. Med andre ord: i denne sammenhæng defineres barok(teater)begrebet som enevældens kulturelle manifestation i dens teatral(sk)e dimension; og det bruges til at pille en enkelt modstilling ud, som vil blive forfulgt fra Frankrig til Danmark og desuden sat i relation til tidens overordnede spændinger - og til slut også til reaktionen mod, opbruddet fra den metafysiske, »barokke«, enevælde.

\section{Stråleglans og skygge}

Ser vi nu først på en billedlig fremstilling af majestæten over dem alle (fig. 1, stik af N. Habert), Solkongen i al hans glans - i en typisk propagandakomposition fra en genre, der i særlig grad var knyttet til regimets selvpromovering, nemlig de pragtfulde, billedrige gigantalmanakker, der celebrerede store og ærefulde begivenheder med kongen i hovedrollen - så springer mange af de allerede skitserede temaer umiddelbart i øjnene. Almanakken er fra $1683 \mathrm{og}$ udgivet $i$ anledning af Hertugen af Bourgognes fødsel - hvortil der refereres i 
medaljonerne på hver side. Den altdominerende figur er imidlertid Ludvig selv, der som den strålende Apollon kører hen over himlen og spreder lys i verden. Motivet er centralt i styrets billedlige selvfremstilling. En af de betydeligste fontæner i Versailles' parkanlæg præsenterer netop Solopgangen vist som Apollon, der styrer de fire gyldne heste, placeret $p \AA$ øst-vest aksen op mod de kongelige appartementer. ${ }^{2}$ Louis-Apollon var kongens tilnavn, især i hans strålende yngre dage. Billedet gentages flere steder inde i slottet, ikke mindst i Apollon-salonen, som var tronsalen, viet til solsymbolikken og med et cirkelrundt loftsmaleri af guden i sin vogn trukket af fire heste og ledsaget af de fire

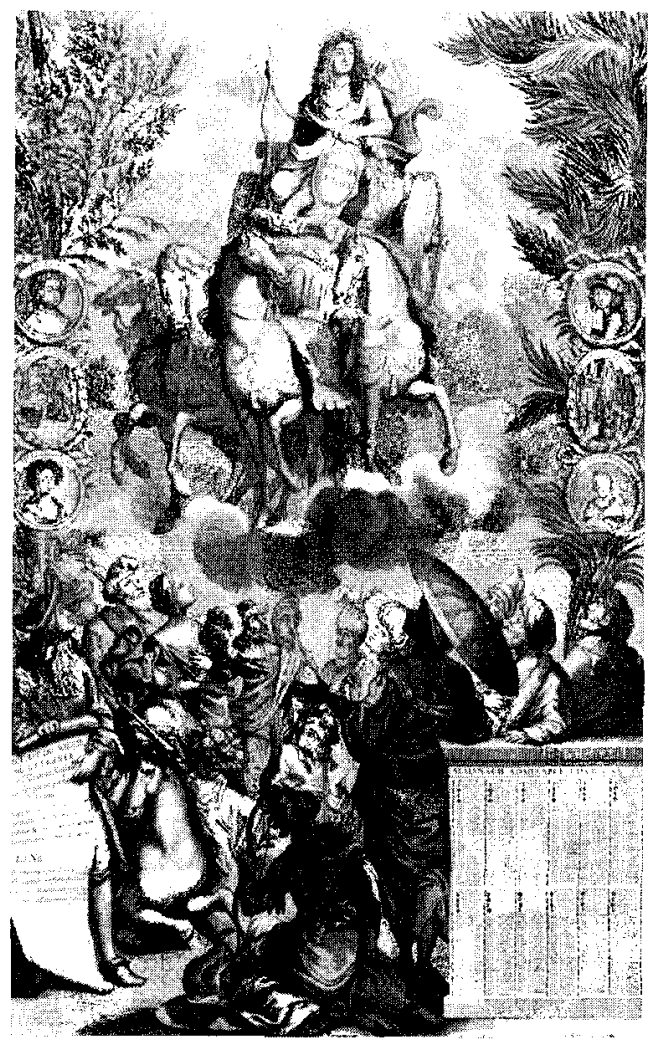

Fig.1 årstider. Almanakken er samtidig - men ikke identisk - med loftsmaleriet. Den er komponeret over et oppe og et nede, et guddommeligt og et jordisk plan, et lysende og et dunkelt felt. Epifanien udbreder sig over hele universet: fra vesten til østen - symboliseret ved et løvtræ til højre og et palmetræ til venstre - over de fire kontinenter, Europa, Asien, Amerika, Afrika, vist ved fire menneskeracer og deres symbolske dyr. Monarken kører frem i solgudens lignelse - og med moustache og allongeparyk - $i$ en antik triumfvogn trukket af fire fleur-de-lys smykkede heste. Hans blik, mine og attitude udtrykker, i overensstemmelse med billedet af den ophøjede hersker ${ }^{3}$ ubevægelighed, distance, grænsende til passivitet. Dynamikken placerer sig i mylderet om ham. Han er, siger inskriptionen, »le Soleil de la France«, og det ikke bare i overført betydning: med rene ord meddeles det, at han er giveren af »fertilité« og »felicité«, af grokraft og lykke. Forestillinger som vi normalt opfatter som primitive eller arkaiske, om gudekongen som frugtbarhedens garant, formulerer sig her i klare, umisforståelige termer. ${ }^{4}$ Fra avlingen af (barne)barnet til præsentationen af 
den (for)samlede menneskehed og natur er budskabet klart: velfærd og vækst udgår fra ét kraftcenter.

Netop forkyndelsen i de himmelske regioner af fødslen lader et andet billede skyde sig ind over Apollon-myten: englen i skyen og hyrderne på marken, frelserens underfulde komme. Men der er lag på lag af billeder; indtoget i Jerusalem med viftende palmer; en apoteose, en triumferende opløftelse i den himmelske zone, som i barokkens trompe l'oiel kirkeloftfresker netop kan inddrage eksempelvis de fire kontinenter i hyldesten; ${ }^{5}$ dommedag, faderguden og apokalypsens fire heste der lader sig syne i skyen etc., etc. frem mod en betydningsmæssig universalitet, der udsiger evighed, almagt, allestedsnærvær.

Et komplekst billede altså; og en anskuelig fremstilling af at virkeligheden først åbenbarer sig og træder i karakter på et ophøjet, symbolsk niveau. Først gennem sin rolle manifesterer herskeren sin sande identitet. Og den er guddommelig, universel og magisk.

Ludvig 14. var én inkamation af et evigt væsen. Historien er ergo ikke tid, men samtidighed: den nu værende hersker er ét med den mytologisk-metafysiske dimension, på samme tid i og uden for tiden.

Ser vi herefter på en anden fremstilling af et triumferende indtog (fig. 2, stik af J.-B. Bonnart) - som er to år yngre, nemlig fra 1685, og ligesom det foregående stammer fra en gigantalmanak, dog her i satirisk-parodisk version

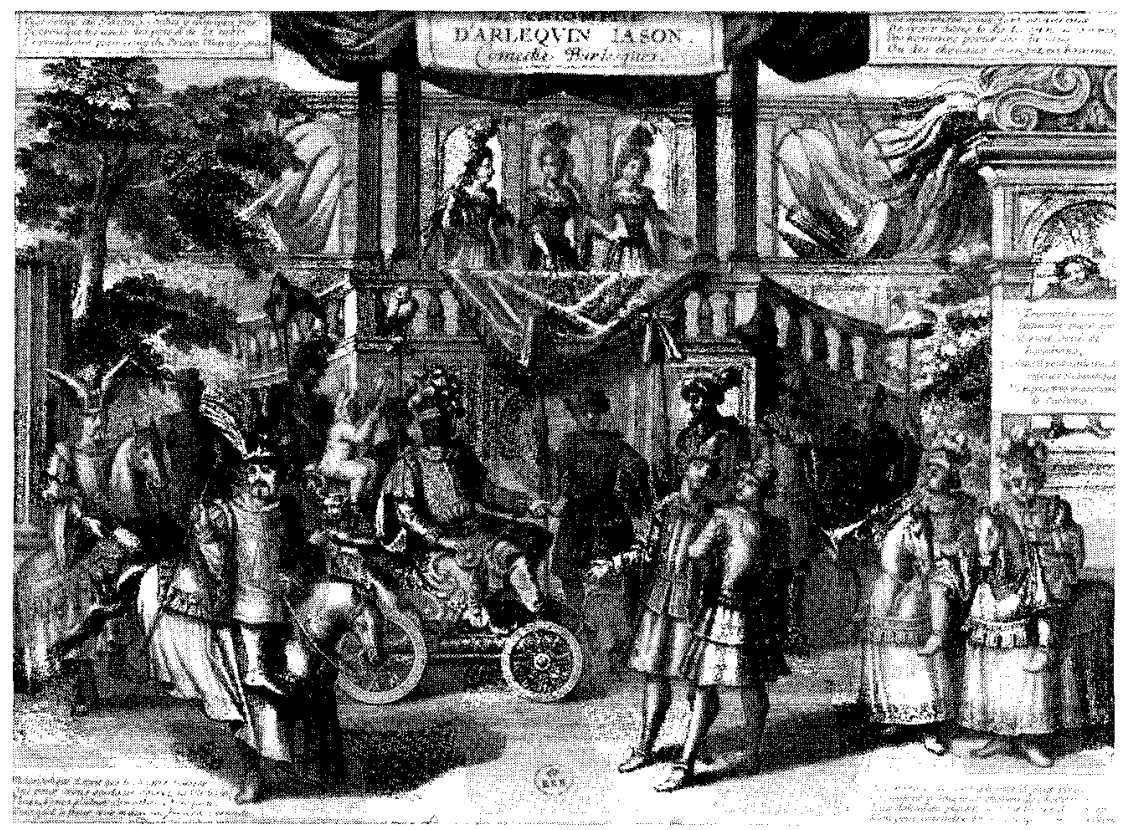

Fig.2 
- så er der forskelligt der straks springer i øjnene. Billedet, som er et udsnit af almanakken, viser den kongeligt ansatte italienske masketrup i Paris, Théâtre Italien, hvis repertoire i bogform i øvrigt blev en væsentlig inspirationskilde for Holberg. ${ }^{6}$ Det gengiver et optrin fra burlesken Arlequin Jason ou la Toison d'or, som forholder sig parodisk til Pierre Corneille's kongehyldende pragtforestilling La Toison d'or, der netop havde været genopsat i Paris. Hos italienerne forvandler Medea i sin skinsyge den heroiske Jason til den groteske Harlekin, som herefter gennemspiller den klassiske handling på såre tvetydige præmisser. Stikket viser »Le triomphe d'Arlequin Iason...«, heltens hjemkomst med de tapre argonauter efter en maritim sejr. »Triomphe de...« er en konventionel kliché i bl.a. tidens almanakker. Ser vi på de officielle almanakker, ${ }^{7}$ som blev udsendt det år, finder vi typisk titler som »Les actions heroiques de Louis-le-Grand« og »Gênes bombardée par l'armée navale de la France - den ydmygende afstraffelse af Genova fra søsiden. I stikket af sejrherren fra søslaget, Harlekin Jason, føjer enkeltdelene - træer, heste, draperier - sig om den centrale mytiske hero, der med en imperialt bydende gestus drager mod højre gennem billedet på sin triumfvogn, udstyret som den guddommelige Ludvig på det forrige billede. Krigens og magtens officielle insignier flankerer ham - pauker, fasces, søjler etc. - ja, selv det universelle tema antydes: i venstre side har vi faktisk et løvtræ og i højre en palme, som på stikket af den ganske verdens tilbedelse af Solkongen! Men: midt i dette kompakte opbud af ophøjet pomp blander der sig udtryk og fragmenter fra et andet univers som totalt omkoder det samlede udsagn. Thi den antikke triumfvogn (ofte i tidens ikonografi forspændt symbolske dyr) trækkes ikke af vælige gangere, men af - svin! Og heltens trofæer udgøres af - skinker, pølser, et grisehoved, en parmesanost... De drabelige krigeres og trompeternes ridedyr er hobbyhorses og på de ledsagende tekster siges det, at det knap er til at skelne mennesker fra dyr. De går så at sige i ét. Denne nærmest vulgære udkrængning af mad-, drikke- og animalsk kropslighedstemaer peger i én ganske bestemt retning, nemlig mod karnevallet og dets billed- og værdiverden. Herfra skriver sig narrefyrstens triumf omgivet af stegespid med sulemad og en grotesk hird af mere eller mindre deforme figurer evt. omgjordet af hesteattrapper. Og skulle man være i tvivl om læsningens holdbarhed, så hjælpes man godt på vej af en af de indsatte inskriptioner. Der står nemlig, at man endelig ikke skal tage fejl af at dette er Jasons triumf, selv om:

»Je crois que les amis des pots et de table le prendront pour celuy du Prince Mardy-Gras«,

vennerne af bordets glæder ville forveksle den med selveste Kong Karnevals 
indtog!

På samme måde som der bag den heroiske Harlekin Jason på triumfvognen sidder en lille abe, som »fordobler « heltens i forvejen dyriske fjæs - således leverer et optrin som dette et perfekt modbillede til det officielle herskerbillede. Det kan ikke læses uden at blive lagt oven på det officielle billede. Dets pegen ud på en obskøn og fordækt billedverden uden for teatret og under den autoriserede kultur bliver ganske manifest ved inddragelsen af genuine karnevalstriumfbilleder (fig. 3-4,). Dem findes der et utal af. Her ses tydeligt,

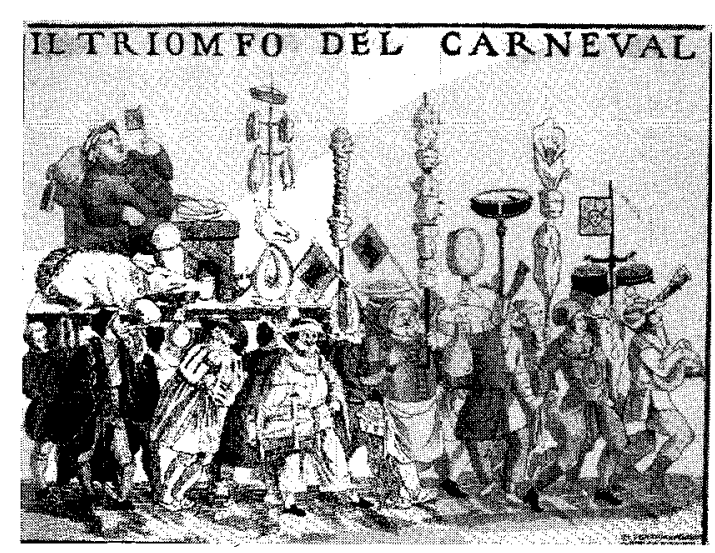

Fig.3

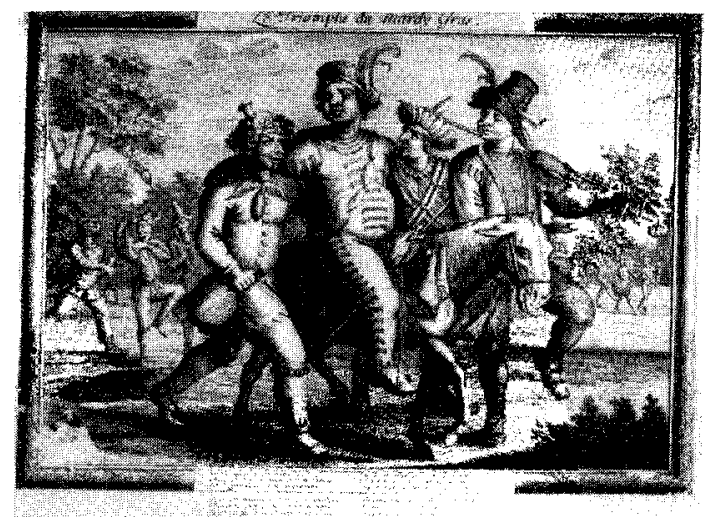

Fig.4 bl.a. på det anonyme italienske træsnit $I l$ triomfo del Carneval, det ubændige anarkis indtog som ét stort mobilt køkken der rykker i marken mod højre med grise og stegespid, larm og ballade, og tilmed et svin for hans majestæt kong Karnevals fødder, næsten som på billedet af Harlekin Jason/Le Prince Mardy-Gras. N. Bonnarts stik af Le Triomphe du Mardy Gras, Fedetirsdags Triumf, er udsendt af det samme grafiske værksted, som det der udsendte Harlekin Jason almanakken; på et vist niveau har de to stik samme motiv. I det ene tilfælde $i$ ren version. I det andet indfældet $\mathbf{i}$ visuelle referencer til den omnipotente majestæt.

Flere betydningsuniverser med anknytning til flere kulturelle lag væver sig med andre ord sammen og afkodes komplekst $\mathrm{i}$ læsningen af billeder som disse. En sådan mental rekonstruktion lader sig selvklart kun praktisere ved inddragelse af forskelligartede udtryksdimensioner. Thi heller ikke barokken op- 
levede på en enkelt snæver fagdisciplins præmisser - historie, kunsthistorie, religionshistorie, teaterhistorie, antropologi... Den centrale betydningsgenerator var dog uden tvivl den my tisk-patriarkalske kongefigur.

Det næste billede (fig. 5, stik af N. Bonnart) forestiller samme Harlekin i den italienske trup, Domenico Biancolelli, i en farce fra 1688 med titlen Arlequin grand Visir. Det er atter en fremstilling med tilknytning til almanak-genren der er tale om. Samme år blev der af officielle almanakker ${ }^{8}$ udgivet en del, der hyldede »La grande Victoire « over tyrkerne i Ungarn, refererede til »Le grand Turc «, »Le grand Visir« o.l. Det, vi ser, er indledningssituationen, hvor Harlekin skyller i land på den tyrkiske kyst. På den udførligere almanak-inskription berettes der om »Harlekin denne uforlignelige aktør/ kaldet søn af tønden og den store Jupiter« - eller på fransk »fils de la tonne et $d u$ grand $J u$ piter $\ll$.

Dette er åbenlys galskab. Spørgsmålet er så, om der er metode i den? Mystikken i det tilsyneladende nonsens løses op, når man - atter - går vejen rundt om den kongelige

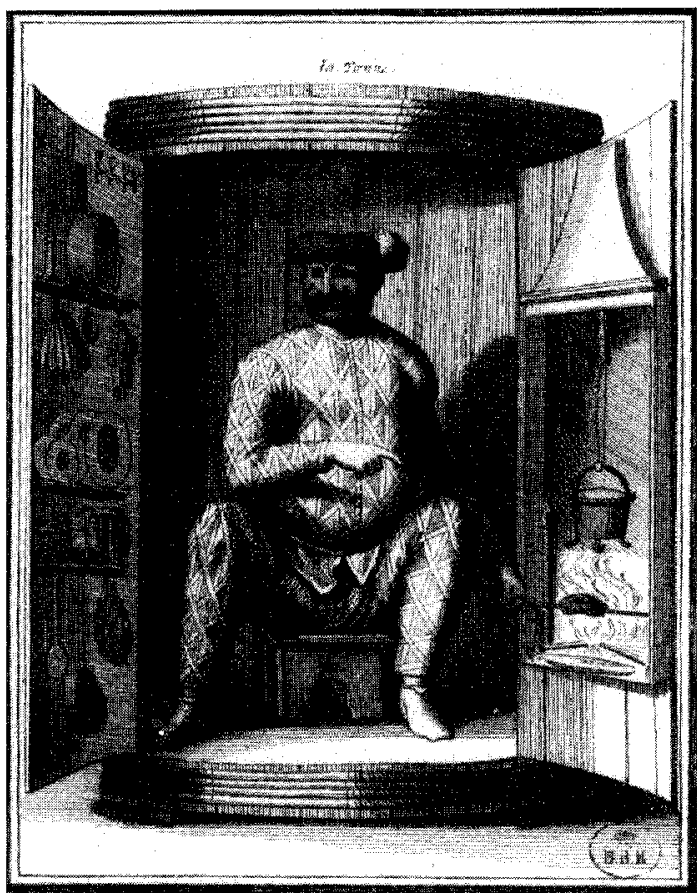

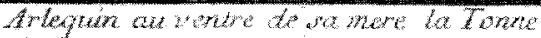
Fig.5

mytologi. Sagen er nemlig den at »la tonne « kan læses - eller høres - »Latone«, dvs. Latona eller i den græske version Letho; med andre ord den nymfe som er mor til Apollon, Solguden. Og det er jo netop, som allerede nævnt, omkring Apollons lignelse, at Ludvig 14. bygger den kultiske symbolik i anlægget af Versailles op. En af de celebreste fontæner i Versailles' park, placeret mellem Solopgangen (se ovenfor) og slottet, præsenterer netop Apollon som »Søn af Letho«, med andre ord »Fils de Latone«. I den håndskrevne guide til parken erklærer Ludvig, at ved denne fontæne bør man dvæle. ${ }^{9}$ Intet under, thi her vises, med motiv fra Ovids Metamorfoser, hvorledes nymfen beskytter sine børn med gudernes konge, Apollon og Diana, mod usle angribere, som 
ved guddommelig mellemkomst forvandles til frøer, dvs. elendige vandvæsener. Den politiske allegori til Fronde-kampene var klar, de givetvis yderst traumatiske begivenheder som lå forud for lanceringen og konsolideringen af den radikale absolutisme.

Harlekin er altså søn af Jupiter - ligeledes et af monarkens klassiske symbolnavne. ${ }^{10}$ Med sin tønde er han endvidere en Bacchus - som tilmed netop er søn af Jupiter og dertil mindre salonfähig bror til Apollon eller »Apollon «, forstået som herskeren i hans symbolske identitet! De mytologiske krydsreferencer knytter narren og kongen ganske intimt til hinanden. Harlekin er en grotesk refleksion af eller tvillingebror til herskeren. Han er en narrekonge.

Denne dobbelte konge-lighed har en lang tradition bag sig: the Mock King, Lord of Misrule, le Prince des Sots osv. I Frankrig var den satiriske narrespilinstitution blevet forbudt midt i 1500-tallet; analoge tendenser ses i en række lande. Også karnevalsmanifestationerne er genstand for forbud og forfølgelse. ${ }^{11}$ Men narrefyrstebilledet er i den grad arketypisk, at det ikke lader sig mane i jorden, behovet for infantilt-profanerende obskøne billeder, for at gøre Nar af den store Far. At en sådan dynamik gør sig gældende i en periode med en massiv accentuering af herskerfiguren, er vel ikke uforståeligt. Det modsatte ville have været mere mærkeligt.

Men det er ikke blot på det mere abstrakte niveau, at Harlekin i tønden kobler sig til narrefyrsteinstitutionen. For ikke blot er det en tønde, der vises, men den er tillige et veludstyret køkken med ildsted, grillspyd, pølser m.v. Hermed er vi atter ovre i karnevalsikonografien. En relation ses eksempelvis i Breughels bekendte maleri fra 1559 af Karnevals ledingstogt, siddende på en valdig

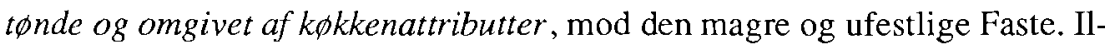
den og overfloden, ofte konkretiseret i køkkenbilledet, er fast inventar i kamevalsmetaforikken, med stærke referencer til underliv, underverden og underbevidsthed - de dimensioner der manifesterer sig i karnevalskulturen. En overflod af pølser i dette udtryksregister har både gastronomiske, seksuelle og fækale betydninger, med kroppen som central metafor. Komiske masker og figurer udgår heraf - som Zan Salsiccia og, mere velkendt på vore breddegrader, Hans Wurst! Harlekinbilledet viser netop en sådan ildfuld åbning med seksuelle og infernale overtoner (faktisk hed den middelalderlige mysteriespilscenes helvedesgab »chappe-« eller »gueule d'Hellequin« efter den dæmonskikkelse, Harlekin som komisk figur udgår af). Og Harlekins bredbugede figur forstærker den visuelle kobling til den bagvedliggende figur, karnevalskongen, jfr. de fyldige fyrster på de indtogsbilleder, vi så i forbindelse med Harlekin Jasons triumf (fig. 3-4). På det helt infantile plan er det selvsagt tillige Harlekin »på tønden«, billedet viser. De kropslige referencer er særdeles bastante.

Men ikke blot i visuel henseende arbejder disse henvisninger til et kulturelt 
anti-univers. Ser vi på opbygningen af handlingen, »fablen«i farcen, da træder de samme strukturer frem. ${ }^{12}$ Efter sin mirakuløse ilandskylning udgiver Harlekin sig nemlig for selveste Muhammed og udnævnes til »Grand Visir«, fejres og hyldes, men afsløres, fratages sin magt og dømmes til døden. Dette er i kort begreb gangen i den myte, der manifesterer sig i karnevalsriten. Drømmen om et væsen som på forunderlig vis indtræffer fra en anden dimension, fantasiens, underverdenens eller hvad det nu er, for en tid praktiserer et »forkert《 styre, demaskeres, detroniseres og eksekveres. Går vi den aktuelle Harlekin, Biancolellis, repertoire efter, ser vi da også, at netop den falske fyrste er en hans faste roller - med kulminationen i Kejseren af Månen, dvs. landet som ikke er, L'Empereur de la Lune, Le Roy Soleil's antipode. ${ }^{13}$

Imidlertid skal man ikke af al denne tale om karnevalskultur og modbilleder lade sig forlede til at tro, at vi har at gøre med romantisk marginaliserede eller forhutlede »gøglere«. Truppen var som nævnt kongeligt ansat, og Harlekinen Biancolelli en sat og velstående borgermand - og i øvrigt medlem af dét Hel-lige Sakramentes Broderskab, der tidligere var faret så hårdt frem mod bl.a. Molière, og som bl.a. udmærkede sig ved sin karnevalsfjendskhed... Et eksempel blandt utallige på at flere hinanden udelukkende sandheder på forskellige niveauer er gyldige samtidig.

De fyrstelige figurer i den symbolske dimension lader sig, som vi allerede har set et eksempel på, gerne skue i antikt-imperialt antræk. Det gælder hvad enten vi taler om den regerende monark - eller om de heroiske figurer, der færdes i det klassicistiske drama, i Corneilles og Racines tragedier. De bærer

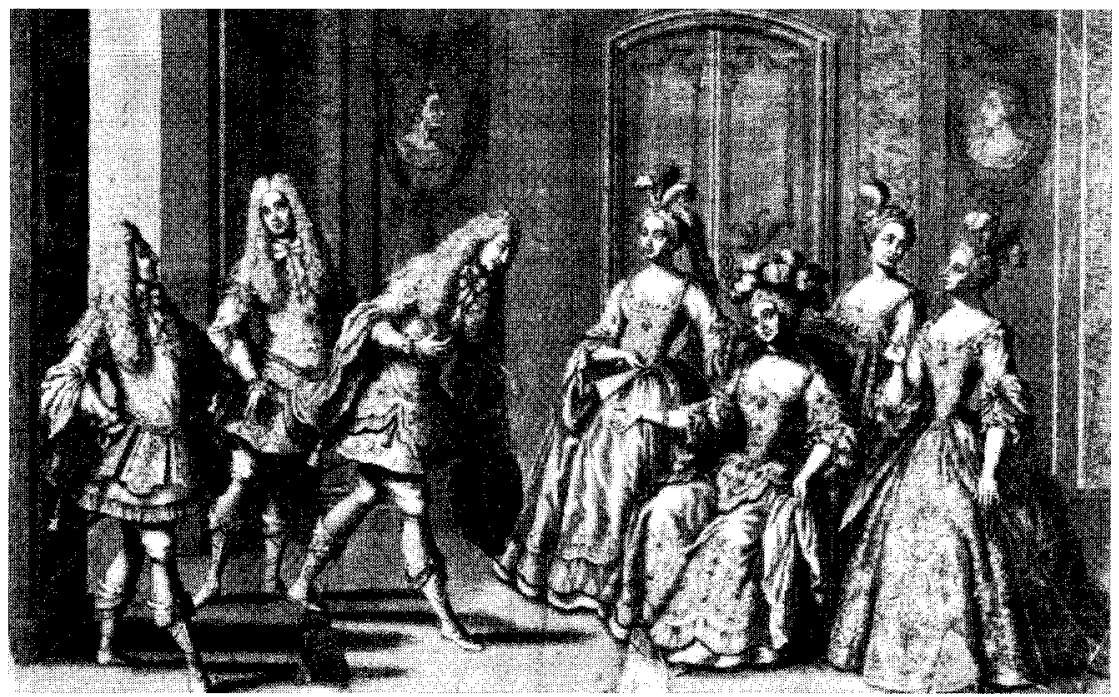

Fig.6 
hovedbeklædning med pragtfulde plumager, allongeparyk og »romersk «strutskørt. En kostumering uden reference til anden virkelighed end regimets symbolske dimensioner. På stikket fra Comédie Francaise, ca. 1700 (fig. 6), ses det konventionelle seriøse barokteaterudstyr, en artificialitet der skaber sine egne koder, sit eget system af betydningsreferencer. Som i indledningsbilledet af den metafysiske hersker er der netop ikke tale om noget begreb om historisk tid. Men om et mytisk-symbolsk univers, hvis tegn skriver sig fra samme betydningsområde som kongeskikkelsens billedverden. Som genre er der ingen tvivl om, at tragedien bearbejder konflikter og spændinger netop med relation til kongeskikkelsen. ${ }^{14}$ Den kunne undertiden gå ganske tæt på. Således antages det, at Racines Bérénice direkte refererer til Ludvigs private konflikt mellem følelse og pligt $\mathrm{i}$ billedet af regenten Titus der må give afkald på sin kærlighed til den fremmede dronning. I Harlekinaden Arlequin Protée (fig. 7-8, stik af J.B. Bonnart), dvs. »Harlekin Proteus«, fra 1683 parodierer Harlekin bl.a. dette pompøse dilemma i fuldt »romersk « udstyr. Men ak, det er kun lånte fjer, lejet heltemundering. Og ustandseligt deklamerende afklædes Harlekin Titus det fornemme kostume af den marskandiser, han havde lejet det af. Han detroniseres, som den falske fyrste, han er. Men også ophøjetheden eller opstyltetheden klædes af.
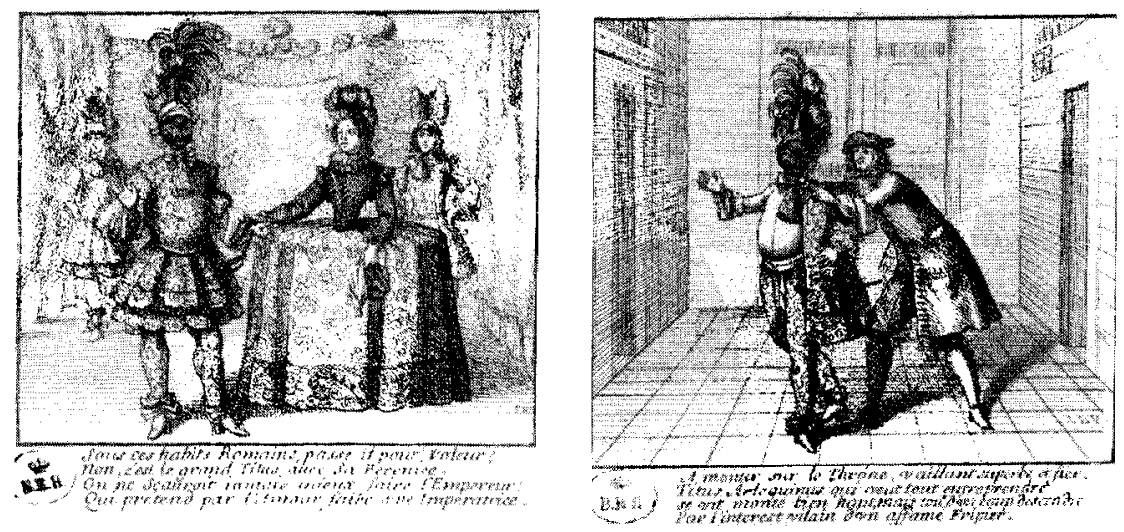

Fig.7-8

\section{Glans og afglans}

Hermed er vi allerede ovre i den nordiske afdeling af denne fremstilling. Thi netop den situation - den antikke helt med de pompøse lader, der ribbes for sin 
heroiske mundering - dette billede er genialt hugget af Ludvig Holberg i den første af hans to egentlige harlekinader Ulysses von Ithacia fra $1723 .{ }^{15}$ Stilen er stærkt inspireret af det i foregående afsnit nævnte Théâtre Italien. I denne komedie ses hele barokuniverset med dets guder og helte og udziirede stil. Helten i farcen, den tapre Ulysses, må i slutningen inkassere den ene latterligg ørende ydmygelse efter den anden, herunder ikke mindst uafladeligt deklamerende at blive klædt af så godt som til skindet af to »klædejøder«, der kræver de kostumer tilbage som de fattige aktører ikke har betalt leje for! De skal bruges til maskeraden i aften. Der står i dialogen:

$\gg$ Ulysses: Hvem er saa dristig, at han tør vakke mig op af min $S \varnothing v n ?$

2. Jøde: Dat bin ich. Mussier kennet wohl Ephraim.

Ulysses: Jeg kender dig ikke, o Ridder!

2. Jøde: So kenner ich ham, Mussier!

Ulysses: Jeg er den store Ulysses von Ithacien.

2. Jøde: Und ich bin die kleine Jude Ephraim.

Ulysses: Jeg er den, som har forstyrret den ædle Stad Troja, Asiens Zierat og Øye-Steen. (...) Jeg er kommen hid for at tage en blodig Hevn af min troeløse Gemahl Penelope.

2. Jøde: Und ich bin hidkommen um Bezahlung for mine lante Klæer zu fodren. Aber det skal ablaaffen ohne Blut.

Ulysses: Jeg kand see paa dit Skiæg, at du est en vandrende Ridder. (...)

2. Jøde: Mussier! ich heb kein Tyt, ich muss die Kleidung utlanen zu ein Masquerade von Abend.

Ulysses: Tør du lægge Haand paa mit kostbare Legeme? Pak dig strax fra mig, eller du skal føle Effecten af min Vrede.

2. Jøde: Træk ju man ut (: klæd dig af), oder du skal følen die Effect von Lands Lov und Gerecht.

Ulysses: Ach Himmel! saadant skal hende mig efter 40 Aars Landflygtighed!

\section{De trakker Kiolen af ham, sigende:}

Bist du in fyrretive Jahr weg gewesen so muss du auch für fyrretiv Jahr bezahlen. Wir wollen strax Reichnung machen. Adiøs saa lang!... « ${ }^{16}$

Fiktionen bryder sammen, da en uden for scenen liggende virkelighed bryder ind og demaskerer den symbolsk-heroiske højheds hulhed - et sammenstød mellem mytisk og rationel tid med selve teatersituationen som grundlæggende metafor. Det er ganske raffineret. 
At stykket er en parodi på en konkurrerende tysk skuespillerbandes pompøse $\gg$ Haupt- und Staatsaktionen $\ll$ er velbekendt. ${ }^{17}$ Udover brødnid er motivet herefter at ramme en tilbagestående og »urimelig«, dvs. ikke-fornuftig, dramaturgi. Spørgsmålet er om satiren rækker længere end som så, hvis vi benytter lejligheden til at zoome ind på tidens danske betydningsunivers.

Betragter vi den danske enevælde, indført ved statskuppet 1660, og især dens (visuelle) lancering af sig selv, er det uden videre klart, at forbilledet er Ludvig 14.'s Frankrig, hans guddommeligt sanktionerede, universelle regime. Men det er i andet og mere end den ydre fremtræden, dette gør sig gældende. Hører vi således ordene ved den første kronede enevoldskonges salving, $\mathrm{Chr}$. 5.'s, som fandt sted i 1671 i Frederiksborg Slotskirke, så viser det sig, at biskop Hans Wandal anvender præcis de samme skriftsteder og argumenter, som dem der lød ved Ludvig 14.'s salving. Kongen er guddommelig, er og bliver konklusionen. I sin præken sagde bispen bl.a.:

»Derfor giver og Herren selv Kongerne den Ærestitel at han kalder dem Guder og den allerhøjestes Sønner, og der er ingen over disse jordiske Guder og de have ingen at gøre Regnskab for uden den himmelske Gud alene (...) og ligesom ingen kan sige til Herren: Hvad gør du? saaledes kan heller ingen kræve Kongen til Regnskab (...)« Også solsymbolikken, en af arketyperne $\mathrm{i}$ al kongekult, indgår: »Gud aabenbarer sig i Kongerne lige som Solen i dens Straaler... $<^{18}$

I anledning af salvingen skrev Thomas Kingo et hyldestdigt, hvor kongen, dronningen og rigets stormænd sammenlignes med solen, månen og stjernerne. Jeg hidsætter enkelte vers:

»Dag op i salig Tid, sølvøjet Østenskanse!

Lad Solen dejlig frem i Purpurkaaben svanse og lægge Himmelsmil på alle ting, den ser at de sig yndelig mod denne Dag beter.

Der træder Solen frem med Prunk og Kongefore; straks falder Ydmyghed paa baade smaa og store; de Stjemers Blink og Brask forblegned svøbes ind, til Kongen vender sig og faar et andet Sind.

Så mangt et Naadeblus og himmelgunstigt Øje han plejer til sit Folk imidlertid at bøje.

Hans majestretisk Bryst er cirkelfuld af Magt; ${ }^{19}$ 
i hver en Straale er en kraftig Virkning lagt.

Han øser Liv og Lyst på alle Stjerneflokke, han bøjer ofte sig til Jordens Vaade-Sukke og stikker Kvægningskraft i hendes kolde Bryst, når Vinter-Voldsmand har forkrænket hend' og kryst.

I Havets dybe Vom han tit sit Spir nedstikker og udi Fiskehal en Skaale net opdrikker: saa løftes Saften op om Tronens gyldne Ring og øses siden ud til al den tørstig Ting... $\ll^{20}$

Som i det franske kongebillede er majestæten den over alt rækkende livgivende kraft. Metaforikken holder sig: i 1737 anprises eksempelvis Chr. 6. således:

»Lev Landets Fader! Lev! Vor Ære, Sol og Lykke, næst den usynlig Gud vor synlig Gud og Smykke... ${ }^{21}$

Herskeren er solen. Og han er (en) gud. Han er den store Far. Det centrale begreb i tankegangen er suveranitet. Den er absolut og apriorisk.

I den danske enevældes hjertekammer, audienssalen på Frederiksborg Slot indrettet af Chr. 5., finder vi en komposition der i alle måder modsvarer eksempelvis Versailles' symbolske strukturer - og dermed også en billedlig fremstilling som det allerførste franske almanakstik, der blev analyseret. Rummet er således bl.a. disponeret over de fire kontinenter, hvert repræsenteret ved et symbolsk billede. Og budskabet er det samme: det universelle kongedømme. Fra de øverste regioner i dette kosmiske rum rækkes kongekronen ned til monarkens billede: magten er af himmelsk herkomst.

Endnu tydeligere bliver denne læggen-sig-op-ad Solkongen måske i Magnus Bergs tegning af Chr. 5. (fig. 9) højt i skyen hævet som Jupiter og residerende over alle jordiske idrætter. Det er en kongelig apoteose, der vises, kongekronen som martyrkrone så at sige, i et komplekst antikt-kristent univers af ikke egentlig protestantisk observans. Chr. fremtræder som parykklædt imperator: historien ikke som tid, men som symbolsk dimension. Hans trone bæres af himmelske væsener, driftighedens genier står hos, en med et ror, en med en merkurstav. Personifikationeme af kongens valgsprog Pietate et Justitia sidder ved hans fødder. Placeret på en hoben militære trofæer er majestætens livs genius ved at slukke hans fakkel. Historiens muse tolker hans ry, som Fama udbasunerer for den ganske verden. I de lavere himle fylkes frugterne af kon- 


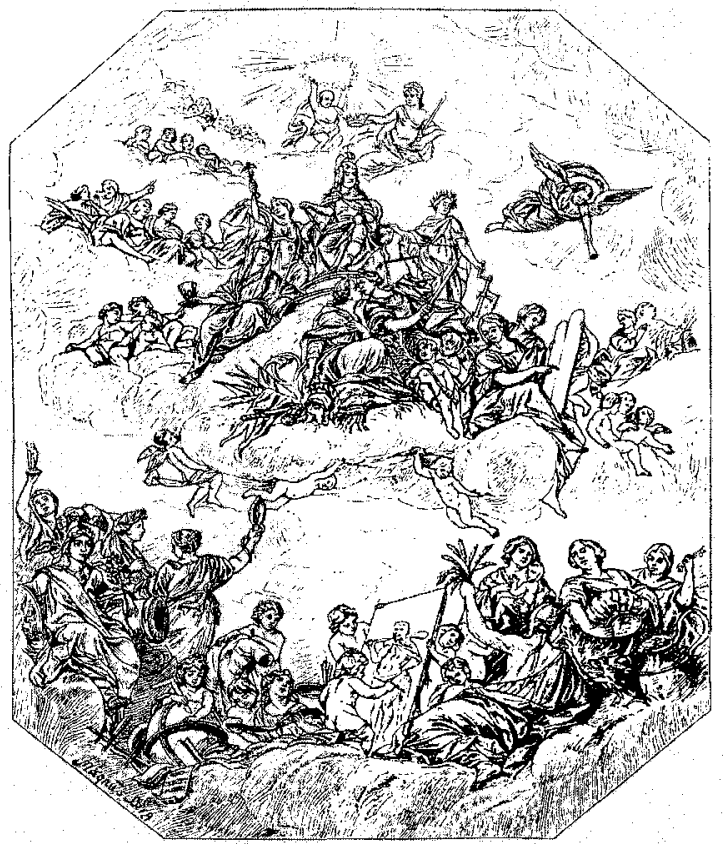

Fig.9 gens velsignelsesrige virke: Ceres med aks og overflødighedshorn, en frugtbar moder, perler og dukater. Og ovenfor: kongens visdom, styrke og storhed $\mathrm{i}$ krig som i fred $i$ et bredt allegorisk register. Midtfor udfolder kunstens og videnskabens genier sig, bl.a. i arbejdet med et maleri af heroen Herkules, givetvis en spejling af majestæten selv. ${ }^{22}$

Ved Chr. 5.'s begravelse var et stort transparent spændt op over facaden $p a ̊ ~ K \emptyset$ benhavns Slot, en apoteose af den

døde konge der ager hen over himlen i antik triumfvogn. Dermed er vi helt tæt på det totale sammenfald med forbilledet. Det er jo det, det indledende billede af Ludvig 14. som Solguden præsenterede.

Der er tale om et sammenhængende udtryksregister. Da Chr. 6. døde i 1746, blev hans lig, ifølge avisen »Extraordinaire Relationer«, iklædt »Romansk Dragt udi en prægtig Drap d'Argent $«{ }_{,}^{23}$ der dog rimeligvis er en variant af den rituelle salvingsdragt; således klædt blev eksempelvis Ludvig 14. bisat. Her vises imidlertid, hentet lidt længere nede fra på rangstigen, en anden variant af et »dødens teater«, det Marselis'ske mausolæum, af Ths. Quellinus, fra Århus Domkirke 1704 (fig. 10). Hele to ægtemænd paraderer her, næsten som på en scene, efter døden deres betydningsfuldhed manifesteret ved antikke brynjer, skørter etc., samt overvældende allongeparyk. Rollen skriver sig ud af et særdeles veletableret symbolunivers. 
Interessant er her naturligvis kongens/stormandens billedlige udstyr som romersk imperator med allongeparyk. At det var en rolle, en symbolsk identitet, herskeren også rent fysisk tog sig på, anskueliggøres ved en række billeder (fig. 11-14) med tilknytning til carrouselgenren, dvs. de symbolske blandinger af maskarade og rytterturnering som blev praktiseret ved hofferne. Siden blev det navnet på en markedsattraktion.

Først to malerier på Rosenborg ca. 1690: Chr. 5. som »romersk « carrouselrytter (figur 11);

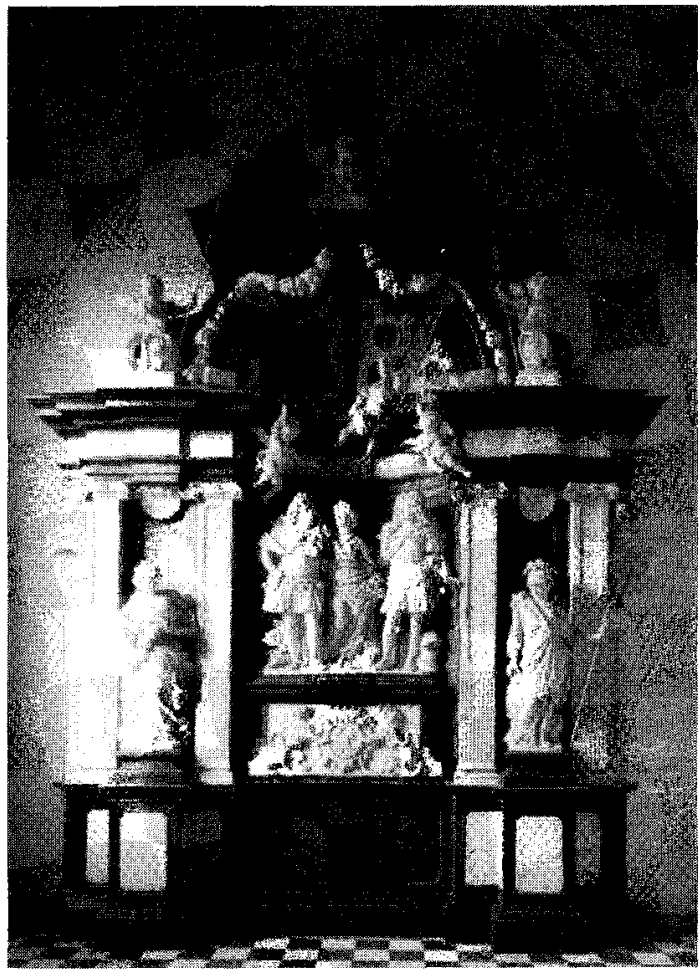

Fig.10 og kronprins Frederik (4.), »Holbergs konge« (figur 12). Endvidere et samtidigt svensk eksempel, Carl 11.'s kroningscarrousel, stukket af C.G. Eimmert (figur 13); og endelig (figur 14) forbilledet, Ludvig, ved den store carrousel i

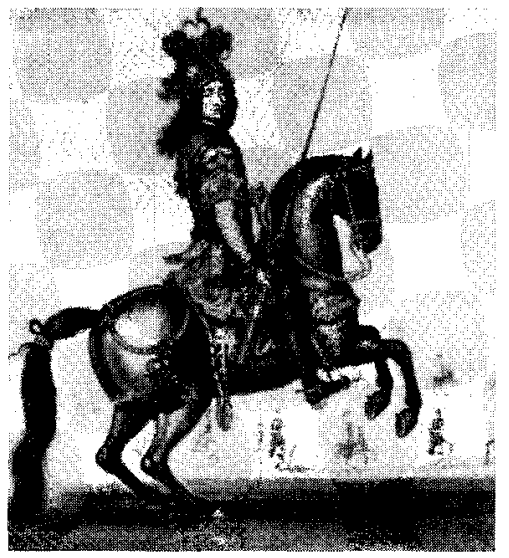

Fig.11

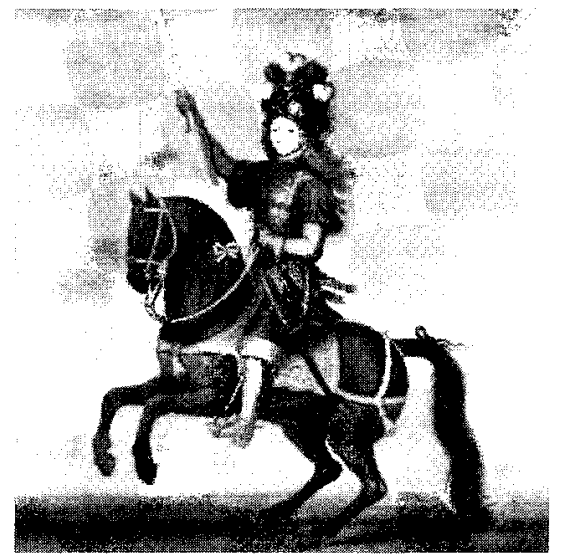

Fig.12 


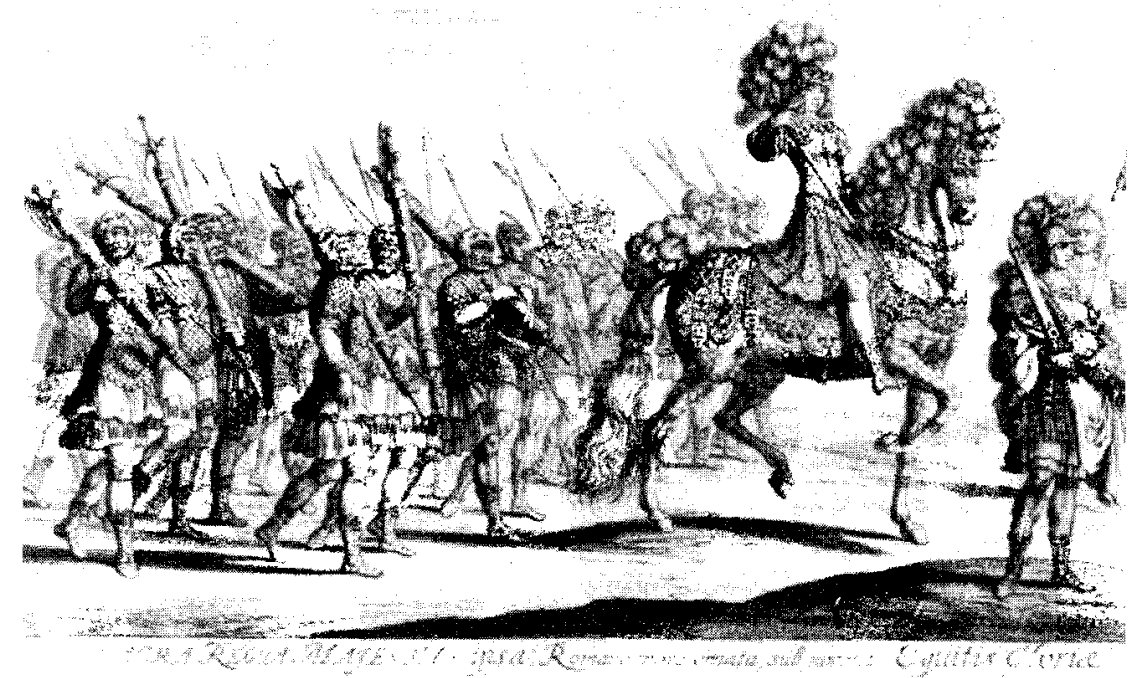

Fig.13

Tuillerierne 1662 (her i en gengivelse fra Ch. Perraults officielle Festiva ad Capita, 1670), hvor Ludvig agerede som solsystemets centrum med rigets stormænd om sig i et symbolsk-hierarkisk planetarium, med andre ord samme struktur eller komposition som i Kingos ovenfor citerede salvingsdigt til Chr. 5. Overensstemmelserne også i den visuelle fremtræden er frapperende: absolutismens fremtrædelsesformer er som flere gange nævnt såre homogene.

Ser vi nu på de heroiske figurer i den teaterform, Holberg kommenterer med sin Ulysses-harlekinade, kan det forbavsende nok konstateres, at der p̊ det visuelle niveau er tale om et totalt sammenfald inden for to genrer, der $\mathrm{i}$ andre henseender regnes for så at sige at negere og dementere hinanden: det

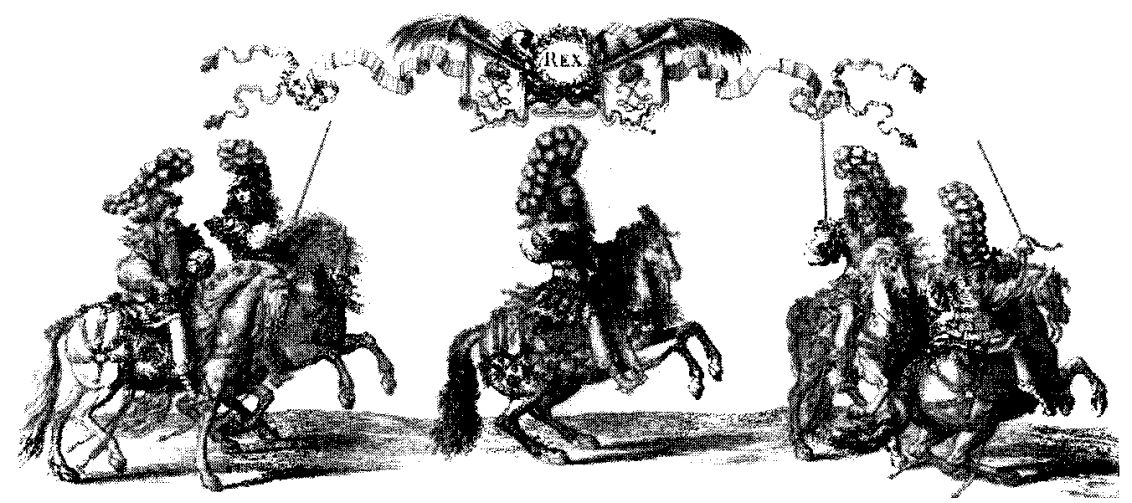

Fig.14 
fransk-klassicistiske drama - som også i Danmark blev opført i fuldt »romansk « udstyr - og den førnævnte tysk-nederlandske Haupt- und Staatsaktion genre (fig 15, stik af M. Engelbrecht (se omslagsillustrationen); sml. fig. 6). Den franske klassicisme er kendt for at arbejde efter overordentlig stramme og målrettede principper, uden spring i tid og sted eller distraherende svinkeærinder i handlingen: dramaet anskuet som et lille urværk, således som Staten søgtes udviklet til en stor maskine under Ludvig 14. Modsætningsvis er den såkaldte vandretrupdramaturgi springende og associerende, episodisk og episk, uden smålig skelen til såkaldt sandsynlighed eller rimelighed, hvad angår tid og sted og fiktion. Holbergs projekt gik bl.a. ud på i fornuftens og oplysningens navn at bekæmpe disse vildtvoksende, »u-naturlige « irregulariteter, denne metafysiske formørkelse og tilbageståenhed, og i hvert fald i teorien at plædere for den franske dramaturgi.

Men med hensyn til de seriøse personers visuelle fremtræden er der altså tværtimod tale om fuldstændig overensstemmelse mellem de to teaterformer. Vi ser i såvel fransk som tysk-nederlandsk heroisk drama plumagerne, det artificielle »romerske« look, blandet med umiskendelige barokingredienser, og først og fremmest det obligatoriske »antikke« strutsk ørt.

Visuelt kan vi således nu konstatere en kobling mellem på den ene side den guddommeligt sanktionerede absolutismes fremtrædelsesform på det symbolsk-metafysiske niveau. Og på den anden side konventionen for skildringen af ophøjede personer i dramatisk form, være sig fransk eller tysk. Denne overensstemmelse, fra konge til komediant, demonstreres ved et eksempel fra 1680 , hvor statholderen Ulrik Frederik Gyldenløve efter carrousellen i København forærede sine to romanske dragter til de franske hofaktører til brug på scenen. ${ }^{24}$ Den officielle ideologi og praksis' karakter af teatralitet bliver herved aldeles nærværende. Og ligeledes identificeringen af regimets metafysiske dimensioner med udtryksformer, der for en modernist som Holberg forbindes med affektation og unatur.

Det er ikke så mærkeligt. Holbergs udgangspunkt i naturretten ${ }^{25}$ implicerer et syn på kongemagten, som på afgørende vis bryder med den metafysiske absolutisme. Hvor denne, som vi har set illustreret på så mange måder, opererer med en overmenneskelig dimension, hvori kongemagten placerer sig - jfr. de rent fysiske indplaceringer i de himmelske regioner i fremstillingerne af eksempelvis Ludvig 14. og Chr.5. - da så at sige afmonterer Holberg-retningen den øvre dimension og plæderer for den opfattelse, at enevælden af rent fornuftsmassige årsager er den eneste funktionelle styreform; den menneskelige natur indebærer tilbøjeligheden til alles destruktive kamp mod alle; derfor har menneskene via den af Gud i dem nedlagte fornuft erkendt det praktiske i at magten delegeres til én person, der som en ansvarlig fader hersker over sit 
hus, fordi det er formålstjenligt og dermed $i$ overensstemmelse med naturens lov; ikke fordi det står i mystisk kontakt med kosmiske kræfter. Det er den ny tids rationelt-praktiske, prosaisk-nøgterne embedsmandstænkemåde, der giver sig til kende, accentforskydningen bort fra kongeguden hen mod det velfungerende administrationsapparat som for at fungere må rense ud i alskens gammel irrationalitet, til hvilken altså faktisk også den »barokke«kongeideologi i praksis henregnes. I sidste instans er det i høj grad også et resultat af en oprindelig radikalt-reformatorisk tankegang, der netop så forestillingen om en mytisk magisk dimension med deraf afledt ritualitet som tom teatralitet: miraklernes tid var bogstaveligt talt forbi. Det over tid og sansning hævede frakendes realitet ${ }^{26}$ - men foreløbig uden at tankegange føres ud i sin yderste konsekvens. Det vil vøre for vidt at komme nærmere ind på her; nævnes skal det blot, at netop den katolske kirke hørte til blandt Holbergs faste fobier.

Treenigheden Gud, Natur, Fomuft ligner herefter et nyt absolut.

Holbergs reform kan altså $\mathrm{i}$ kort begreb siges at rette sig mod teatraliteten eller den symbolske dimension, der jo, som vi har set, gerne antager mytologisk form. I hans første store og i mange måder programmatiske udspil, Peder Paars, 1719, er det netop det mytiske univers, der får sig en tur i det satiriske syrebad. Og man skal så her være opmærksom på, at de politisk-filosofiske implikationer i den operation ikke er helt ubetydelige. Det er grundlæggende fortolkningsuniverser, der bringes i konflikt. Og altså ikke kun latterligt, når krænkede kredse forlangte bogen brændt af bødlen på torvet under henvisning til Danske Lov. Ikke mange årtier tidligere var den skæbne faktisk overgået et skrift af oplysningsfilosoffen Chr. Thomasius, som anfægtede kongemagtens guddommelighed! ${ }^{27}$

Paradokset er da, at Holberg så at sige bruger teatret til at uddrive teatraliteten. I Ulysses von Ithacia ved at etablere et meta-plan, repræsenteret ved Harlekinen Chilian, ${ }^{28}$ der uafladeligt peger hen på, at den komedie der spilles, det heroiske ritual der opføres, netop blot er en komedie, som konstant dementeres af den materielle virkelighed - $\mathbf{i}$ dette spil med et helt register af fiktionlag går Holberg endog så radikalt til værks, at han glimtvis lader den skuespiller, der agerer Harlekin/Chilian, fremstå under eget navn - så at det brutalt demonstreres, at det som fremstår som ren og tom form uden substans, rene udtryk uden manifest indhold og mening, pr. definition er teater, komedie, og livsfarligt og dødbringende, hvis det ikke erkendes som sådant. Den altdominerende dødssynd i det holbergske univers handler om svigtende evne til at gennemskue fiktionen, at skelne udenværkerne fra substansen; den som ikke formår det, rammes af den dramatiske retfærdighed og udleveres ynkeligt til latteren, jfr. den citerede slutscene fra Ulysses von Ithacia. Og utallige analoge optrin i komedierne; grundskemaet er, at det dramatiske subjekt i tiltagende 
grad slipper grebet om virkeligheden, mister selverkendelsen og arbejder sig ud i et fiktivt univers, hvor kulminationen af uvirkeligheden truer med at sprede død og ødelæggelse omkring sig, for så sluttelig at rammes desto hårdere af den virkelighed, der slår tilbage i en latterliggørende forløsning efter at have været fortrængt til det ubærlige. Også i Ulysses von Ithacia ligger dette voldens brændpunkt i midten, hvor det mytiske univers så at sige går i spin og begynder at dementere sig selv, da den blinde sandsiger Tiresias står af, ${ }^{29}$ nægter at deltage i det pompøse spil og derved anfægter fiktionens eller teatralitetens realitet. Der er en dyb indre logik i at for at dette anslag kan afværges og herskerens autoritet opretholdes, så må narren opofres, Chilian, dvs. Harlekin, henrettes. Og først ved at overtrumfe fiktionen og teatraliteten, ved at agere en rolle som den aldeles nonsens-artede profet Nabocodonoser, er narren i stand til at virke overbevisende og troværdig på ordenens repræsentanter og garanter.

Den raffinerede dialektik i Holbergs projekt handler i høj grad om teatret som eksistentiel metafor: kun den der ikke tager spillet for pålydende har mulighed for at overleve. Og som det vil være fremgået er det i høj grad også barokkens teatralitet, dens angiveligt indholdsløse ritualitet, der af helt overordnet filosofisk-politiske årsager er genstand for Holbergs angreb. Den indplaceres på linie med alskens nedarvet magi, ceremoniel og irrationalitet. Kun den borger, der formår at skelne teatralitet fra realitet, kan indgå som velfungerende komponent i statsmaskinen. Den barokke metafysik må derfor afsløres og latterliggøres - for at kunne blive demonteret, livsfarlig og dødbringende som den i den sidste instans er.

\section{Universet revner}

Går vi nu tættere på komedien om Ulysses von Ithacia må det for det første konstateres, at teknikken her er helt tydelig: herskeren er en nar, hildet i irrationalitet, narren derimod den rationelle, og på helt enkel vis: ved publikumshenvendelser, der jo bryder »illusionen«, sørges der uafladeligt for at modtageren, tilskuerne, identificerer sig med narren og altså ser herskeren gennem narrens øjne. Der manipuleres på ganske elementær vis med synsvinklen, i pædagogisk øjemed.

Spørgsmålet er så dernæst, om disse tematiske modstillinger kun arbejder på et helt generelt plan - hvor deres betydning til gengæld også forekommer tydelig - eller om det er muligt at påvise mere specifikke relationer til tidens mere eller mindre fiktive virkelighed.

Ud over at se komedien som et intenderet lystmord på den konkurrerende 
tyske teaterform - også fra den kendes i øvrigt konstellationen Kongen og Narren (Hans Wurst) - så har man diskuteret, om måske yderligere en hofopera af Frederik 4.'s hamburgske operister over Ulysses-motivet skulle tages med i betragtning, når talen var om mulige forlæg; ${ }^{30}$ operisterne holdt en tid ugentlige offentlige forestillinger på Slotsteatret, og de betragtes som de danske aktørers rivaler. Man er nok gået bort fra tanken, bl.a. med den kompositoriske begrundelse, at satiren hos Holberg så åbenbart rettes mod dramaturgiske udskejelser som brud på de fransk-klassicistiske regler om tidens, stedets og handlingens enhed - men disse regler overholdes faktisk i vidt mål i den tyske Ulysses-opera... Her stopper så diskussionen. Men det er ikke helt sikkert, den behøver det.

Denne tyske operaform er et spektakulært-heroisk musikdrama med megen mekanik og bombastiske handlinger. Altså i realiteten en musikalsk version af Haupt- und Staatsaktion genren, helt ud i de imposante »romerske « heltekostumer. Hamburgeroperisterne var i 1721 blevet ansat af Frederik 4. i stedet for den franske hoftrup. De valgte med forkærlighed deres sujetter i det mytologiske område, antikt eller nordisk, og lod gerne skinne igennem, at de pompøse helte var tegnet med forbillede i jordiske monarker - evt. i forventning om kontant belønning. Således også i operaen Ulysses, førsteopført i november 1722 , der blev til i anledning af kongens fødselsdag, og hvis hovedbudskab er en anprisning af det kongelige ægtepars uforlignelige troskab. Med til den historie hører også, at monarken havde praktiseret ægteskaber »til venstre hånd«, dvs. ladet sig vie til en elskerinde, samtidig med at han, som var garant for det kristne ægteskab, var gift med dronningen. Den daværende dronning, Anne Sophie, var således tidligere hans hustru til venstre hånd. Det var dybest set bigami, og det var der dødsstraf for. Men i den flerdimensionalitet af komplekse virkeligheder, absolutismen ubesværet opererede i, betød det ikke nogen uoverkommelig selvmodsigelse. Faktisk havde kongen indhentet teologisk sanktion. Målt med den konkret-nøgterne alen - jfr. ovenfor om den holbergske anti-metafysiske attitude - kunne en sådan kongelig praksis dårligt beskrives som andet end et spil, et rituelt teater i konflikt med den faktiske virkelighed.

Undersøger vi nu opbygningen af operaen Ulysses, så ser vi der i en prolog Jupiter fremføre en lovtale over monarken: ingen har i dette rige udrettet så meget som han! Neptun uddyber anprisningen. I øvrigt går selve handlingen ud på, at altimens Ulysses’ hustru Penelope på Ithaca værger sig mod bejlerne, smeder den onde troldkvinde Circe sine rænker - hun har i dette værk af hensyn til stedets enhed forladt sit rige for at følge den standhaftige Ulysses og om muligt overvinde hans dydighed. Den træskes anslag slår fejl, og i en epilog presenteres vi for »Tiden«, der fremfører, at selv om Ulysses’ klogskab og 
Penelopes troskab vil huskes evigt, så blegner dog disse berømte antikke personer i sammenligning med Frederik og hans gemalinde, hvorfor undersåtterne opfordres til for den ganske jord at prise og forkynde det herlige pars magt og berømmelse. Ingen trivielle jordiske realiteter griber distraherende ind i dette ophøjede rollespil.

Sammenholder vi så med Holbergs Ulysses-harlek inade, så er det klart at det er krigstemaet, den absurde trojanske krig der praktisk taget aldrig finder sted - bortset fra i hærførernes puerile fantasi - , der er nok så centralt frem for troskabstemaet (som dog langtfra er sekundært). Men i og med at de to værker ligger så relativt tæt på hinanden i tid, spejler farcen i en vis forstand af sig selv helteoperaen. Sammenstiller vi herefter med prologen i Ulysses von Ithacia finder vi således dér ikke gudernes konge, men »Iris eller Regn-Buen, den store Junonis Fruer-Pige«, altså gudernes dronnings tjenestepige, en komplet omvending i køn, status og synsvinkel:

"... Min Forretning er den samme hos Juno, som Mercurii er hos Jupiter«. Fare og føjte må hun på grund af »min store Frues Jalousi og Mistænkelighed, thi saa snart Gudernes Monarch kaster sine Øynes naadige Straaler paa en Nymphe eller Hyrdinde, blir min Frue strax allarmeret...« Så hun har fuldt op at gøre med »at straffe den Nymphe eller Hyrdinde, som Jupiter har fattet Elskov til. Men ingen Tiid er saa besværlig som denne forbandet 11. Junii; thi som min Frue er den største Dame udi Himlen og paa Jorden saa har hun ogsaa de største Rente-Penge at indfordre... $\ll^{31}$

Temaet om den ægteskabelige troskab i de højeste kredse får sig straks et ordentligt skud for boven. Og det kobles med det samme på økonomi-temaet i en ganske brutal afkridtning af kontrasten mellem en symbolsk og en nøgternt-kommerciel virkelighed. Forretninger spiller en stor rolle i Ulysses von Ithacia, helt frem til sammenstødet mellem rollen og regningen i slutningens afklædningsscene, som blev citeret $\mathrm{i}$ indledningen til forrige afsnit.

Netop i de sidste to akter, hvor Circe - her i parodisk udgave af Dido - driver sit spil, og ikke mindst i slutscenerne tilbage i Ithacien, spiller troskabstemaet imidlertid den helt centrale rolle: Ulysses har trodset lidelser bg fristelser blot for at vende hjem til en mær, der ligger i med det samlede hold af bejlere! Altså, ved sammenstilling med operaens epilog, atter en total omvending. Her krakelerer Ulysses' symbolske univers, hvad der dog ikke forhindrer ham i at udbryde i højstemt-barokke alexandrinere, der besværger hele universet, projicerer hans tragedie ud til kosmiske dimensioner: 
»Om man fra Østen gaaer til Vesten, nøye søger, Opkaster, læser og igiennem-blader Bøger, Man paa Utroeskab ey skal finde større Speyl. Ved Himlens Bistand dog min Hevn skal ey slaae Feyl.

Thi før skal mænges Jord, Luft, alle Elementer, Med Verdens Undergang som man at see forventer; Før Verdens Bygning selv skal løses, gaae i grund, Før jeg skal mere see, før jeg skal nogen Stund...«32

hvorpå verset bryder sammen og helten falder i s $\varnothing v n$.

Billedet af $\varnothing_{\text {sten og }}$ Vesten, alle elementerne, ja, hele verdens bygning, der mobiliseres i relation til den mytiske helt, refererer helt klart til billeder som dem af Ludvig 14. og Chr. 5. Pankrator, som bevæger hele universet. Og det symbolske univers' sammenbrud implicerer på det niveau at »hele Verdens Bygning « synker i grus. Bag den dagsaktuelle satire lå billedet af den naragtige konge, ritual-absolutismens faderfigur. Barokkens metafysiske metaforik blafrer i vinden som papkulisser og lejet kluns. Fiktion uden forankring i nogen realitet. Resten er forretning.

Eller rettere sagt: hos Holberg er virkeligheden narrens, han som formår at manøvrere mellem fiktion og realitet, fleksibelt og kreativt, at agere relativt, centrumsløst. Det »naturlige« menneske med tilnavnet Harlekin.

Om der nu i større eller mindre grad er tale om bevidst og direkte parodiog det lader sig vel aldrig afgøre! - så er de to nogenlunde samtidige værker symptomatiske og eksemplariske for et sammenstød mellem betydningsuniverser, der i den følgende tid brydes intenst.

Narren Harlekin endte hos Ludvig 14. med i 1697 at pådrage sig en bortvisning fra den kongelige nærhed og nåde. Det forvrængede spejlbillede var da uønsket. Narren Holbergs komedier adresserede sig primært satirisk til borgerne, faktisk for at gфre dem til sådanne, velfungerende og rationelle. Et hovedsigte var som næunt at lægge en bombe under det symbolske verdensbillede. Når han ved enkelte lejligheder behandler det klassisk-mytologiske univers, kommer han pr. definition også til implicit at berøre og kommentere regimets udtryksunivers og derved dets på langt sigt anakronistiske grundlag. Men han er så professionel en spiller, at han - efter forskrækkelsen med Paars-sagen - undgår selv at komme i klemme.

Hans grundinspiration udgår - ud over Molière - fra den italienske maskekomedie med dens karnevalistisk robuste u-sentimentalitet, dens blanding af animalskhed og fornuft. Chilians rolle har med sine idelige henpegninger på kroppens realiteter adskilligt at gøre med udsagnene i læsningen af Arlequin Jason billedet i indledningen; som når han erklærer at han »skiøtter aldrig om Laurbær, uden jeg seer dem paa en Postey eller Tærte « ${ }^{33}$. Eller når han falder 
ned for at kysse fædrelandets jord, og én da just har kastet sit vand der. Holberg huggede som antydet vidt og bredt fra det repertoire, som netop Harlekinen Biancolelli, der blev omtalt i indledningen, agerede i i Paris. Det var en form for robust komik, der tjente hans formål vel. At den så også havde rod i en folkelig mytologi, har nok medvirket til at gøre den slidstærk. ${ }^{34}$ Er Holberg på et vist niveau nok så meget rationalist, kobler han sig paradoksalt nok i vidt omfang på et karnevalistisk univers.

\section{Epilog}

Til slut skal det siges, at denne kampagne mod den »barokke « spektakularitet jo nok i vidt omfang er lykkedes. Vi er saglige, nøgterne og endimensionelt kedelige. Men selvklart kan det ikke lade sig gøre at eliminere irrationel lyst til spektakularitet. Barokken lever videre. For at anskueliggøre det fremdrages nogle billeder fra det klassiske reservoir for sunkent kulturgods, markedsgøglet, de såkaldte vulgærgenrer. Carrousellen, der blev til karrussel. Majestæten der blev til nar eller gøgler.

Men først endnu et par billeder af kongeligheden og naragtigheden (fig. 1617): Peter Cramers tegning fra Ewalds mytologiske hyldestspil Cereris og Thetidis Strid i anledning af en kongelig mærkedag 1774, hvor hele det allegoriske helteudstyr findes intakt. Og det faktisk - med en eklatant usamtidighed - et par år yngre Kierlighed uden Strømper (ligeledes tegnet af Cramer), der endnu en gang, med en gradvis afklædning af præcis de samme hero-ingredienser som figurerede i Arlequin Protée-stikkene af »Titus« (fig. 7-8), latterliggør den høje stil og demonterer dens velkendte udtryk. Den har siden haft det svært i Danmark. Skal man i vore dage søge inspiration i ikke-naturalistiske, heroisk-episke teatrale udtryksformer, rejser man gerne til den anden

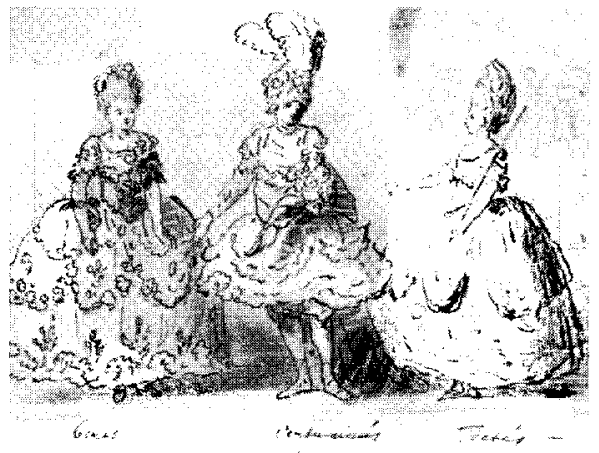

Fig.16

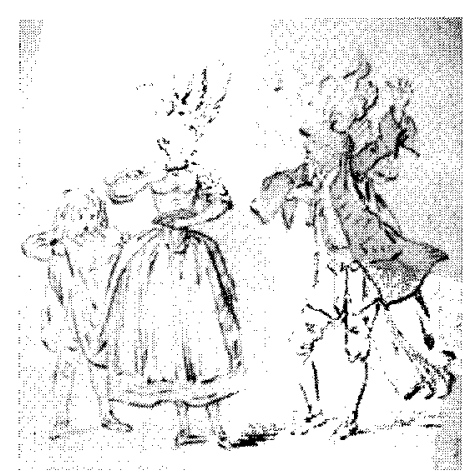

Fig.17 
side af jordkloden for at oplede den rene vare, helst til det fjerne Østen med omliggende provinser. Det strejfer ingen at søge i vor egen tradition. Utvivlsomt bl.a. betinget og blokeret af det historiske had til enevælden og alle dens billeder, efter at en ny betydningsgenerator ved et regulært paradigmeskift først i forrige århundrede blev installeret: »folket«. Men det er fortsættelsen af historien.

Folket har imidlertid som sagt hæget om barokken. Den nederlandske lineakrobat Chr. Roat fik i 1826 spændt et tov ud fra Århus Domkirke ned på torvet. Det gik godt. Men da han fors $\emptyset$ gte at balancere fra Rosenborg og ned i Kongens Have, styrtede han og omkom ynkeligen. Hans dragt er en fuldkom-

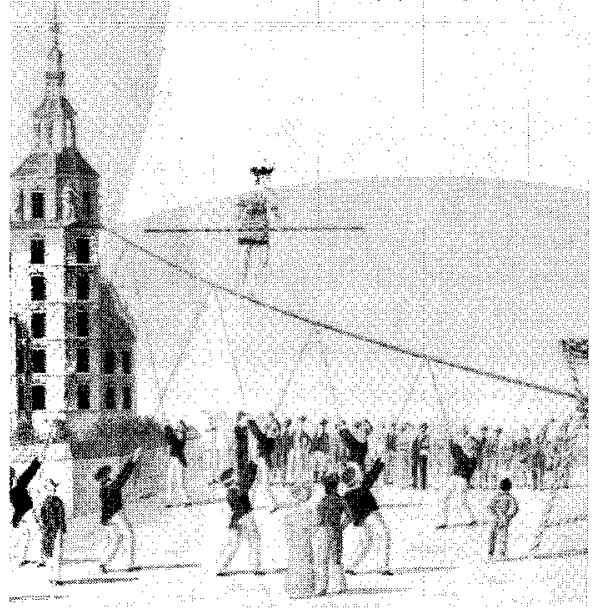

Fig.18 men replik af de forne himmelske majestæters (fig. 18). Og artisterne fra forrige århundrede (fig. 19, stik af Joh. Blaschke; fig. 20 foto Berlin 1863) gentager $\mathbf{i}$ alle detaljer kostumet $\mathrm{i}$ Ewalds dramatiske kongehyldning. ${ }^{35}$ Udviklingen fra symbol over teatralitet til spektakularitet er fuldbyrdet.

Barokkens guder, l'ancien régimes konger, blev etapevis likviderede. Mere eller mindre symbolsk. Som det ofte sker, når guddomme »afskaffes « eller tappes for indhold, går de igen i såkaldte vulgærgenrer, i form af grotesker, latterlige, skræmmende eller

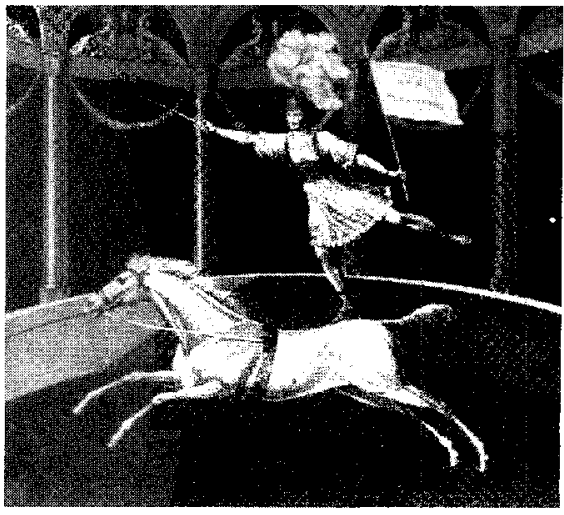

Fig.19

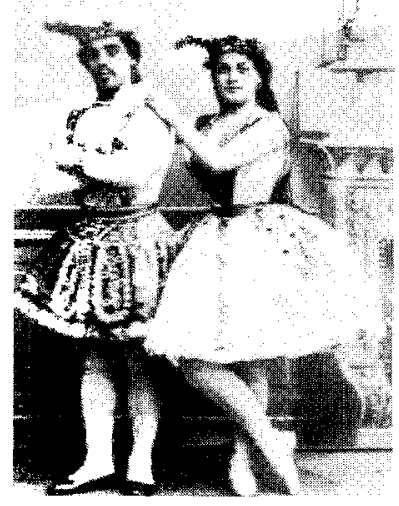

Fig. 20 
spektakulære. I øvrigt er også narren Harlekin som allerede antydet udgået af en gude/dæmonskikkelse...

\section{Noter}

1. Jfr. bl.a. Hugo Johannsen, »Den ydmyge konge « i Kirkens bygning og brug. Studier tilegnet Elna Møller, Kbh. 1983, s. $127 \mathrm{ff}$, Steffen Heiberg, Christian 4., s. 312ff, Kbh. 1988, og Christian IV og Europa, Kbh. 1988.

2. Ild-aksen skæres af en nord-syd orienteret vand-akse. Tanken om, at verdens midtpunkt eller kongens eller gudens bolig befandt sig i et sådant skæringspunkt, er arkaisk, jfr. Mircia Eliade, Myten om den evige tilbagekomst, Kbh. 1966, p. $14 \mathrm{ff}$.

3. Jfr. Peter Burke, The fabrication of Louis XIV, New Haven/London, p.32.

4. At vi kan tale om en betydning som ligger ud over allegorien og propagandaen hænger selvsagt sammen med, at regimet bygger på eksisterende, indgroede forestillinger om kongen som den mytisk-magiske undergører, jfr. f. eks. Marc Bloch, Les rois thaumaturges, Strassbourg 1924, Pierre Goubert, L'avènement du RoiSoleil 1661, Paris 1967 og J.-M. Apostolidès, Le roi-machine, Paris 1986. Styrets - forstået som det kompleks af betydninger og institutioner der sædvanligvis benævnes »kongen « - konkrete selvforståelse manifesterer sig da også på niveauer som stikker langt dybere end de rent statsretsligt-teologiske. Ritualiteten havde karakter af egentligt ritual. Selv de materielle objekter med relation til kongen forlenede han med en art hellighed, da hans person var hellig. Det var således en krænkelse at vende ryggen til majestætens portræt, at gå ind i hans tomme (!) soveværelse uden at knæle, eller at gå med hat i det rum hvor der var dækket op for kongen, jfr. Peter Burke o. c. (se note 3), p. 90. I Akademiet, parlamentet, Louvre, Hôtel de Ville var der altid en stol med de kongelige insignier. Han brugte den aldrig, men man knælede for den og ærede den, som var han til stede.

5. Således i Andrea del Pozzos afbildning af Ignatius af Loyola's optagelse i himlen i S. Ignazio kirken i Rom. Mht. paimerne er afbildningsmåden tidstypisk og genfindes i triumfporte til den store kongelige entrée i $1660 \mathrm{og}$ i fremstillingen af $\mathrm{Li}$ delseshistorien i Versailles' kapel.

6. Jfr. Hans Brix, »Holberg og Thêâtre Italien« i Edda 11, Kbh. 1919. Teksterne, eller rettere scenarierne, til dels med fransk udskrevne dialoger, blev udgivet af truppens sidste Harlekin, Evaristo eller Evariste Gherardi. Der findes flere udgaver, alle med titlen Théâtre Italien, bl.a. én fra Paris år 1700.

7. Opregnes i Vict. Champier, Les anciens almanachs illustrés, Paris 1886.

8. Jfr. note 6 .

9. Manière de montrer les Jardins de Versailles, udg. Paris 1982.

10. Se bl.a. Peter Burke, o.c. (se note 3), s. $98 \mathrm{ff}$, hvor det eksempelvis nævnes, at der i forbindelse med den under Arlequin Jason stikket nævnte afstraffelse af Genova blev fremstillet en medalje med Ludvig i lyn-gudens lignelse.

11. Jfr. Peter Burke, Popular culture in early modern Europe, New York 1978, p. $218 \mathrm{ff}$.

12. Handlingen er rekonstrueret af C.D. Rouillard i $\gg$ Un Arlequin Grand Visir joué à Paris en 1687 et ses échos au Théâtre de la Foire « i Revue d' histoire du Théâtre 28, Paris 1976. 
13. Eksempler på det satiriske tema om det falske regentskab findes i min disputats Solkonge og Månekejser. Ikonografiske studier i Fr. Fossards Cabinet, Kbh. 1991, bl.a. s. 159ff. En genuin anti-konge som »månekejser«nævnes i Beryl Hugill, Bring on the Clowns, New Jersey 1980, s. 77: »One English Lord of Misrule was George Ferrers, who, to cheer the young Prince Edward, son of Henry VIII, made his solemn entry as a mock king emerging from a representation of the moon." Men det er klart at temaet nar/konge eller narrekonge er klassisk. Eksemplerne er utalte: folkebøgernes Marcolfus, Bertoldo etc. Middelalderlig ikonografisk eksemplifikation fremlægges i J.-Cl. Schmitt, »Les masques, le diable, les morts, dans l'occident médiéval« i Razo, 6, Nice 1986. I sidste instans er der tale om en mytiskrituel arketype.

14. Jfr. N. Ferrier-Caverivière, L'image de Louis XIV dans la littérature francaise de 1660 à 1715, Paris 1981, og J.-M. Apostolidès, Le prince sacrifié. Théâtre et politique au temps de Louis XIV, Paris 1985.

15. Komedien er skrevet før foråret 1723, da den omtales i Just Justesens Fortale. Den formodes iflg. Eiler Nystrøm, Den danske Komedies Oprindelse, Kbh. 1918, s. 96, første gang at være opført i 1724 og er første gang trykt i 3. bind af komedierne, som udkom 1725.

16. Ulysses von Ithacia, Act. V, Sc. ult.

17. Se bl.a. Anne E. Jensen, Helte og anti-helte, Kbh. 1984.

18. Her citeret efter den normaliserede tekst i Reinhold Mejborg, Billeder af Livet ved Christian den femtes Hof, Kbh. 1882, s. 8ff. Som nævnt i indledningen er tankegangen ikke ny. Således lød det ved Chr. 4.s kroning 1596, uagtet rigets status som valgkongedømme, at »... med betegnelsen guder viser han (: Gud), at de (: kongerne) er hans hjælpere, der som et levende og besjælet billede af ham på jorden indtager hans plads og udfører guddommelige hverv og pligter «. Hugo Johannsen, o.c. (se note 1), s. 134. Men med den konstitutionelle absolutisme elimineres modsigelsen og systematiseres indarbejdelsen af budskabet.

19. Man ser for sig det bekendte billede af Ludvig 14. som Kong Sol i balletten La Nuit, 1653, hvor hans magtfulde bryst netop prydes af det runde soltegn.

20. Efter Mejborg (se note 18), s. $18 \mathrm{ff}$.

21. Jfr. FJ. Mejer, Efterretninger om Fredensborg Slot i Frederik IV's, Kristian VI's og Frederik V's Dage, Kbh. 1880, s. 89.

22. Tegningen er formentlig udført 1699, jfr. Mejborg, o.c. (se note 18), s. $128 \mathrm{ff}$, og Birgitte B $\emptyset g g i l d$ Johannsen, »Til evig ære minde $\mathrm{i}$ Kirkens bygning og brug (se note 1), s. 164f. Om begravelsen se Carl Bruun, Kjøbenhavns Historie, II, Kbh. 1887, s. 406 f.

23. Jfr. Mejer (se note 21), s. 96.

24. Viben Bech og Ellen Andersen, Kostumer og modedragter, Kbh. 1979, s. 129, jfr. S. Flamand Christensen, De danske Kongers kronologiske Samling paa Rosenborg. Kongedragterne fra 17. og 18. Aarh., Kbh. 1940, I, s. 113.

25. Om stats- og naturretsproblematikken se bl. a. Julius Paludan, Fremmed Indflydelse paa den danske Nationallitteratur, II, Kbh. 1913, s. 48ff, Kaare Foss, Holbergs Naturrett, Oslo 1934, og Ditlev Tamm, Laerebog i dansk retshistorie, Kbh. 1989.

26. Jfr. Keith Thomas, Religion and the decline of Magic, London 1971.

27. Chr. Bruun, Frederik Rostgaard og hans Samtid, I, Kbh. 1870, s. 199. Passagen i Danske Lov, som implicit involveres i Paars-anklagen, lyder i tillempet sprog: »Skulle og nogle bøger i kongens riger og lande trykkes (...) som kunne have udseende til nogen oprør eller mod kongens højhed eller anden ulempe forårsage, da 
bør ikke aleneste personerne, som sådanne trykke (...) i højeste måde at straffes, men og bøgerne ved bødlen offentlig på ilden kastes og opbrændes «. Se endvidere Københavns Universitet 1479-1979. Det teologiske fakultet, Kbh. 1980, s. $176 \mathrm{f}$.

28. At Chilian er Harlekin fremgår bl.a. af komediens epilog, hvori det hedder: »n Harlequin man ogsaa seer,

Med Snak der Herskab plager..."

og af Holbergs Første levnedbrev, som taler om »Arlequinus servus Ulyxis«. Endelig klarlagt er forholdet af Torben Krogh, som i Studier over Harlekinaden paa Den danske Skueplads, Kbh. 1931, s. 19f, påviser, at Chilian er en plattysk version af Harlekin-navnet.

29. Skiftet ligger præcis midt i teksten, og hér midt i en replik - fra den barokt svungne tiltale til stemplingen af heroerne som narre : »I ædle Græske og Mesopotamiske Helte, hvis store Manddoms-Gierninger har opfyldt alle Verdens Hiørner! I ere alle nogle Narre, og løbe med Liimstangen. Gaaer smukt hiem igien og tar vare paa jere egne Hustruer, og lader mig være i Roe. Gaaer bort.« (Akt III, sc. 2). Et frontalsammenstød mellem retorik og realitet, panegyrik og fysik (kroppens krav), med narrebetegnelsen i centrum.

Den skitserede struktur i Ulysses von Ithacia kan sammenholdes med Jeppe paa Bierget, som følger den samme gang i opbygningen og også efter en barsk afsløringsscene, akt 3 , sc. 2, opererer med narrens, Jeppes, uskadeliggørelse. De to komedier kan med udbytte i videre forstand sammenholdes: Ulysses-stykket viser den grotesk-antikverede hersker, Jeppe-komedien derimod er på ét niveau et Lehrstück i nødvendigheden, af fornuftmæssige årsager, af en suveræn regent, jfr. epilogen. Her aftegner sig et par poler i det holbergske univers, hvis klarhed dog modificeres af Baronens erklærede fascination, akt 5, sc. 6, af irrationaliteten. Her ligger han ganske på linje med sin forfatter.

30. V.C. Ravn i For Ide og Virkelighed, I, Kbh. 1873, s. 542; Torben Krogh, »Det tyske Operaselskabs Besøg i København under Frederik IV « i Aarbog for Musik 1924, Kbh. 1926, s. 88ff; sm., Musik og teater, Kbh. 1966, s. 8off; Anne E. Jensen, o.c. (se note 17 ), s. $66 \mathrm{ff}$.

31. Ulysses von Ithacia, Prologus.

32. Ulysses von Ithacia, Scen. ult.

33. Ulysses von Ithacia, akt II, sc. 7. - Den krigshær, Chilian kommanderer med i akt II, sc. 5 - »Er det ikke et skiønt Regiment? Alle stærke og handfaste Karle, herlig Mondering. Jeg troer, aldrig saadant Regiment Ryttere nogen Tiid er bleven seet $\ll$ - antages almindeligvis at bestå af marionetter. Der er en anden mulighed, nemlig at der er tale om rekvisitheste spændt om maven, altså sådanne som ses på Arlequin Jason stikket (fig. 2), jfr. at der på Slotsteatret iflg. oversigt fra 1724 fandtes »Hest af Pap med Dekke og Støvler«, sml. Eiler Nystrøm, o.c. (se note 15), s. 196.

34. Også herhjemme blev Harlekinfiguren af de teaterfjendske kredse opfattet som ordenens og moralens negation, således hos Erik Pontoppidan, der tillige er stærkt anti-karnevalistisk. Se min afhandling $»$ De talte om Comoedi-Spil som Djevlens Strik og Snare. Teater og teologi under pietismen« i Fønix, 2, Kbh. 1990, s. $99 \mathrm{ff}$.

35. Jfr. det rige billedmateriale i Anders Enevig, Cirkus i Danmark, I-III, Kbh. 1982. Vedr. det nationalt-folkelige temas gennembrud i kunsten - og i Holberglæsningen - i første halvdel af det 19. årh. se min artikel »Omkring Marstrands Holberg« i Katalog til Marstrandudstillingen, Nivaagaards Malerisamling 1992. 